\title{
Degradation of Water-Soluble Fraction of Jellyfish by a Marine Bacterium, Brevibacterium sp. JCM 6894
}

\author{
HARUO MIMURA $^{1 *}$ and SHINICHI NAGATA ${ }^{1}$ \\ ${ }^{1}$ Research Institute for Marine Cargo Transportation, Kobe University of Mercantile Marine, 5-1-1, Fukae, \\ Higashinada-ku, Kobe 658-0022, Japan
}

(Received November 27, 2000_-Accepted March 12, 2001)

We used Brevibacterium sp. JCM 6894, which was isolated from seawater, to degrade the water-soluble fraction of jellyfish. After $27 \mathrm{~h}$ of incubation, the protein content in the supernatant was reduced from 1.97 to 1.31 $\mathrm{mg} / \mathrm{ml}$ with an increase in cell yield of $0.40 \mathrm{mg}$ cell protein $/ \mathrm{ml}$. The missing protein content in the fraction was $0.26 \mathrm{mg} / \mathrm{ml}$. By the cell growth, the content of $\mathrm{NH}_{3}$ was increased from 0.38 to $4.57 \mu \mathrm{mol} / \mathrm{ml}$. The value of chemical oxygen demand, which is a marker of remaining organic compounds in the fraction, was reduced from 890 to $431 \mathrm{mg} \mathrm{O} /$ liter.

Key words: microbial degradation, Jellyfish, marine Brevibacterium sp. JCM 6894

Generally, organic wastes containing water are burned with fossil fuel in a furnace. During this process, greenhouse gases, mainly $\mathrm{CO}_{2}$, which trap the heat radiating from the earth's surface, are released into the atmosphere. To preserve the natural environment and to conserve natural resources, it is important to use environmental microorganisms to degrade organic wastes ${ }^{2,4,5)}$.

Actually, some marine life forms such as blue mussels and jellyfish are degraded efficiently by microorganisms. In summer at atomic power plants for generating electricity, shells grow fast on the inside of the pipes used for pumping in cooling seawater, and a lot of jellyfish become trapped on the wire-mesh filter in the pipes. To prevent operational problems, these organisms are removed at intervals. An excess of organic waste results in spoilage on the ground. Consequently, deodorization is also a factor to be taken into consideration $^{8)}$.

Using a marine microorganism to degrade organic wastes taken from seawater seems to be an ecologically friendly approach. Therefore, in this study, we examined the extent to which a marine Brevibacterium sp. JCM 68946,7) is able to degrade the water-soluble fraction of jellyfish. To assess

\footnotetext{
* Corresponding author; E-mail: hmimura@cc.kshosen.ac.jp, Tel: +81-78-431-6344, Fax: +81-78-431-6365
}

this ability, we used Escherichia coli ATCC 9637 as a reference strain because the type strain grew in seawater ${ }^{1)}$, and $E$. coli itself survived in the marine environment ${ }^{3}$.

Jellyfish were collected from a coastal area near Himeji, Hyogo prefecture, Japan, in early July 1999. The tissues of the jellyfish were immediately destroyed with a juice mixer (MJ-700, Matsuden), centrifuged (3,000×g, $5 \mathrm{~min}$ ) and filtrated (pore size, 5.0 and $0.45 \mu \mathrm{m}$ ) with a membrane filter (47 mm $\phi$, Advantec). The mixture of water-soluble and insoluble fractions obtained just after the destruction of jellyfish had a dry weight of $32.2 \mathrm{mg}$ per $\mathrm{ml}$. By filtration with a pore size of $5 \mu \mathrm{m}$, the dry weight was reduced to $32.0 \mathrm{mg}$ per $\mathrm{ml}$, where the turbidity was 0.07 at $650 \mathrm{~nm}$ (DU 640, Beckman Instruments, CA, USA). To minimize contamination by microorganisms as well as to obtain a pure water-soluble fraction, we re-filtrated the solution with a pore size of $0.45 \mu \mathrm{m}$. After the filtration, the turbidity and dry weight were less than 0.01 at $650 \mathrm{~nm}$ and $31.3 \mathrm{mg}$ per $\mathrm{ml}$, respectively. The solution thus obtained contained 350 $\mathrm{mM} \mathrm{Na}^{+}$and $10 \mathrm{mM} \mathrm{K}^{+}$ions (Compact ion meters, C-122 for $\mathrm{Na}^{+}$ions, $\mathrm{C}-131$ for $\mathrm{K}^{+}$ions, Horiba), and was kept in a refrigerator until use.

Brevibacterium sp. JCM 6894, which was isolated from seawater at Aburatsubo, Kanagawa, Japan, and E. coli ATCC 9637 were pre-incubated for one day at $30^{\circ} \mathrm{C}$ in the 
complex medium $^{7}$. Then $0.5 \mathrm{ml}$ of cell culture was added to an Erlenmeyer flask containing $50 \mathrm{ml}$ of the water-soluble fraction of jellyfish. At a given time, turbidity was monitored at $650 \mathrm{~nm}$ with the spectrophotometer. After $27 \mathrm{~h}$ of incubation at $30^{\circ} \mathrm{C}$, cells were harvested by centrifugation $(10,000 \times \mathrm{g}, 5 \mathrm{~min})$.

After $27 \mathrm{~h}$, the protein contents of the cell-free supernatant and pellet were measured with a protein assay kit (Pierce Chemicals, IL, USA). The concentrations of free amino acids and $\mathrm{NH}_{3}$ in the cell free supernatant were measured with a high performance liquid chromatography system (Waters, MA, USA). The value of chemical oxygen demand (COD) was measured three times independently by a standard procedure as described elsewhere. The measurement of $\mathrm{NO}_{2}^{-}$was carried out with a kit (Ion selective pack test, WAK-NO $\mathrm{N}_{2}$, Kyoritsu).

Fig. 1 shows the growth curves of Brevibacterium sp. JCM 6894 and E. coli ATCC 9637 in the water-soluble fraction of jellyfish. After about $20 \mathrm{~h}$ of incubation, the growth reached a stationary phase. Turbidities at $27 \mathrm{~h}$ of incubation were about 1.5 and 1.0 for Brevibacterium sp. JCM 6894 and E. coli ATCC 9637, respectively. As a negative control, we carried out the incubation with the water-soluble frac-

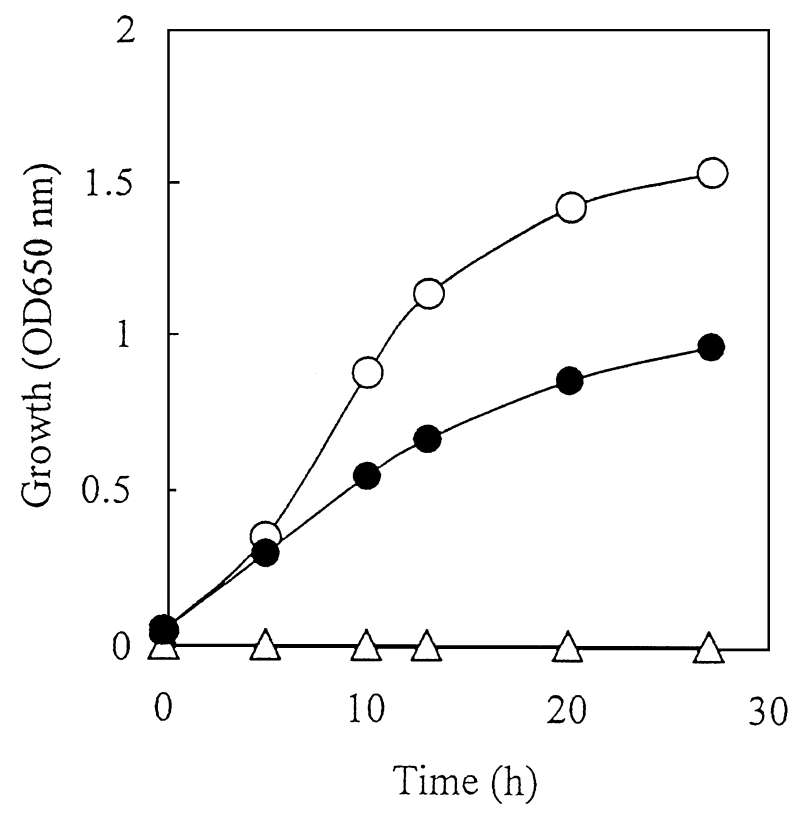

Fig. 1. Growth curves of Brevibacterium sp. JCM 6894 and Escherichia coli ATCC 9637 in water-soluble fraction of jellyfish. Brevibacterium sp. JCM $6894(\bigcirc)$ and E. coli ATCC 9637 (O) were grown aerobically in the solution at $30^{\circ} \mathrm{C}$. As a negative control, the solution alone was incubated without being inoculated $(\triangle)$. At given times, turbidities were measured photometrically at $650 \mathrm{~nm}$. tion alone. It was confirmed that there was no increase in turbidity.

We used plates containing nutrients ${ }^{7}$, $0.5 \mathrm{M} \mathrm{NaCl}$, and $1.5 \%$ agar to detect contamination in the solution without inoculation before and after $27 \mathrm{~h}$ of incubation. We also tried to detect microorganisms other than Brevibacterium sp. JCM 6894 in the solution where the strain had been incubated for $27 \mathrm{~h}$. However, no other colonies of microorganisms were detected after 3 days of incubation at $30^{\circ} \mathrm{C}$.

Bacillus sp. HR6, which was isolated from soil and could degrade organic waste efficiently, especially bean curd refuse ${ }^{4,5)}$, and a halophilic isolate, which was isolated from the jellyfish solution, were used to compare the growth with that of Brevibacterium sp. JCM 6894 and E. coli ATCC 9637. The growth for the two strains, however, did not overcome that for $E$. coli ATCC 9637 even after 27 h of incubation (data not shown).

After microbial degradation, protein contents for both the pellet and the supernatant were measured (Table 1). The initial protein content of $1.97(\mathrm{mg} / \mathrm{ml})$ was reduced to 1.31 $(\mathrm{mg} / \mathrm{ml})$ with an increase in cell protein of $0.40(\mathrm{mg} / \mathrm{ml})$ for Brevibacterium sp. JCM 6894. For E. coli ATCC 9637, the protein content in the supernatant was reduced by 0.29 (mg/ $\mathrm{ml})$ and the cell protein increased by $0.26(\mathrm{mg} / \mathrm{ml})$. Protein contents of 0.26 and $0.03(\mathrm{mg} / \mathrm{ml})$ in the supernatant were missing for Brevibacterium sp. JCM 6894 and E. coli ATCC 9637, respectively.

Table 2 shows the changes in the pool of free amino acids and $\mathrm{NH}_{3}$ in the supernatant of the water-soluble fraction of jellyfish after $27 \mathrm{~h}$ of incubation. The remaining amino acid pool of $2.91 \mu \mathrm{mol} / \mathrm{ml}$ for Brevibacterium sp. JCM 6894 was about two times higher than that for E. coli ATCC 9637. On the other hand, the $\mathrm{NH}_{3}$ content of $4.57 \mu \mathrm{mol} / \mathrm{ml}$ produced by Brevibacterium sp. JCM 6894 was about three times that produced by E. coli ATCC 9637. The content of $\mathrm{NH}_{3}$ increased to be more than ten times higher than the initial value, $0.38 \mu \mathrm{mol} / \mathrm{ml}$.

Brevibacterium sp. JCM 6894 showed higher growth activity in the water-soluble fraction of jellyfish than $E$. coli ATCC 9637 (Fig. 1). By measuring the content of cell protein after $27 \mathrm{~h}$ of incubation (Table 1), we could confirm the superior growth ability of Brevibacterium sp. JCM 6894 in comparison with that of E. coli ATCC 9637.

When proteins, or amino acids, are degraded completely, the final products are $\mathrm{NH}_{3}, \mathrm{CO}_{2}$, and $\mathrm{H}_{2} \mathrm{O}$. After the growth of the Brevibacterium sp. JCM 6894 cells for $27 \mathrm{~h}$, the total content of proteins and free amino acids in the supernatant was reduced to 66 and $37 \%$, respectively. The amount of free amino acids, however, remained large in the superna- 
Table 1. Change in protein content in water-soluble fraction of jellyfish after cell growth.

\begin{tabular}{llccc}
\hline \multirow{2}{*}{ Strain } & & \multicolumn{2}{c}{ Change in protein content $(\mathrm{mg} / \mathrm{ml})$} & Missing protein content (mg/ml) $^{\mathrm{a}}$ \\
\cline { 3 - 4 } & & before & after 27 h & 0.40 \\
\hline \multirow{2}{*}{ Brevibacterium sp. JCM 6894 } & pellet & 0.00 & 1.31 & 0.26 \\
& supernatant & 1.97 & 0.26 & 0.03 \\
\hline
\end{tabular}

${ }^{\text {a }}$ Missing protein content $(\mathrm{mg} / \mathrm{ml})$ was defined as the difference of total protein content before and after cell growth.

Table 2. Changes in free amino acid pool and $\mathrm{NH}_{3}$ in water-soluble fraction of jellyfish after cell growth.

\begin{tabular}{cccc}
\hline \multirow{2}{*}{$\mu \mathrm{mol} / \mathrm{ml}$} & & $\begin{array}{c}\text { Brevibacterium } \text { sp. } \\
\text { JCM 6894 }\end{array}$ & $\begin{array}{c}\text { Escherichia coli } \\
\text { ATCC 9637 }\end{array}$ \\
\cline { 2 - 4 } & before & after 27 h & after 27 h \\
\hline Amino acids & 7.91 & 2.91 & 1.54 \\
$\mathrm{NH}_{3}$ & 0.38 & 4.57 & 1.69 \\
\hline
\end{tabular}

tant in comparison with that for E. coli ATCC 9637. Extracellular proteases might contribute to an increase in free amino acids in the supernatant. We have confirmed that strain JCM 6894 secreted proteases when grown on plates containing nutrients ${ }^{7)}, 0.5 \mathrm{M} \mathrm{NaCl}, 3 \%$ skim milk, and $1.5 \%$ agar. As for E. coli ATCC 9637, the missing protein content as well as the production of $\mathrm{NH}_{3}$ were much smaller than for Brevibacterium sp. JCM 6894. These results indicate that $E$. coli ATCC 9637 is not suitable for degrading jellyfish.

The supernatant was also used to measure the value of chemical oxygen demand (COD) and the concentration of $\mathrm{NO}_{2}{ }^{-}$. Before and after incubation of Brevibacterium sp. JCM 6894 in the water-soluble fraction, the COD was $890 \pm 30$ and $431 \pm 24\left(\mathrm{AV} \pm \mathrm{SE}, \mathrm{mg} \mathrm{O} \mathrm{O}_{2} /\right.$ liter $)(\mathrm{n}=3)$, respectively. The quantified $\mathrm{NO}_{2}^{-}$was 0.5 (mg/liter) initially, a value which did not change even after $27 \mathrm{~h}$ of incubation, indicating that the remaining organic compounds in the cellfree supernatant contribute to an increase in the COD.

We believe that the microbial degradation of organic wastes under aerobic conditions depends strongly on the growth rate of the microorganism used ${ }^{5)}$. A fast growth rate allows the microorganism to become dominant in the targeted organic waste. As Brevibacterium sp. JCM 6894 is halotolerant, we could add $\mathrm{NaCl}$ at up to $2 \mathrm{M}^{6,7)}$ in the solution of jellyfish to prevent the growth of other microorganisms.

Since the COD value was still too high for the degraded solution to be released into the marine environment, an effort to reduce the remaining organic compounds should be made. The pathogenicity of Brevibacterium sp. JCM 6894 is not yet known, however the risk of disease in marine organisms does not seem to be high even if the jellyfish solution degraded by the strain JCM 6894 is released into the sea.

\section{Acknowledgements}

We thank Mr. Kenji Maeda (Sanyo Techno Co., Ltd, Kakogawa) for technical assistance and providing fresh jellyfish. Amino acids were measured commercially at the Himeji branch of the Industrial Research Center of Hyogo prefecture.

\section{References}

1) Ishida, A., Y. Kawatake and N. Ono. 1994. Osmotic stress conditioning for induction of acquired osmotolerance in Escherichia coli. J. Gen. Appl. Microbiol. 40: 35-42.

2) Leschine, S. 1995. Cellulose degradation in anaerobic environments. Annu. Rev. Microbiol. 49: 399-426.

3) Mitchell, R. 1974. Introduction to environmental microbiology, pp. 113-130. Prentice-Hall Inc., New Jersey.

4) Mimura, H., K. Maeda and S. Nagata. 1999. Chromatographic analysis of bean curd refuse decomposed by Bacillus sp. HR6. Biocontrol Sci. 4: 23-26.

5) Mimura, H. and S. Nagata. 1999. Physiological characteristics of Bacillus sp. HR6 in the process of decomposing bean curd refuse. Biocontrol Sci. 4: 105-108.

6) Mimura, H. and S. Nagata. 2000. Isolation of halotolerant microorganisms from seawater around the inland sea in Western Japan. Microb. Environ. 15: 217-221.

7) Nagata, S. 1988. Influence of salts and $\mathrm{pH}$ on the growth as well as NADH oxidase of the halotolerant bacterium A505. Arch. Microbiol. 150: 302-308.

8) Yun, S.-I. and Y. Ohta. 1997. Some physiological properties of microorganisms capable of deodorizing farm animal feces. Bioresource Tech. 60: 21-26. 